\title{
Antioxidant activity of black bean (Phaseolus vulgaris L.) protein hydrolysates
}

\author{
Jarine Amaral do EVANGELHO ${ }^{1 *}$, Jose de J. BERRIOS², Vânia Zanella PINTO ${ }^{1}$, Mariana Dias ANTUNES ${ }^{1}$, \\ Nathan Levien VANIER ${ }^{1}$, Elessandra da Rosa ZAVAREZE ${ }^{1}$
}

\begin{abstract}
The objective of this work was to study the effect of enzymatic hydrolysis of black bean protein concentrate using different enzymes. Bean proteins were extracted and hydrolyzed over a period of $120 \mathrm{~min}$ using the enzymes pepsin or alcalase. The protein hydrolysates' molecular weight was assayed by electrophoresis and the antioxidant activity was evaluated by the capturing methods of free radicals ABTS ${ }^{+}$and DPPH. Electrophoretic results showed that the bands above $50 \mathrm{kDa}$ disappeared, when the beans protein was subjected to hydrolysis with pepsin. The bean protein hydrolysate obtained by hydrolysis with alcalase enzyme, showed higher antioxidant activity for inhibition of the radical ABTS ${ }^{\bullet}$. However, the hydrolysates obtained by hydrolysis with pepsin had higher antioxidant activity for inhibition of the radical DPPH. The use of pepsin and alcalase enzymes, under the same reaction time, produced black bean protein hydrolysates with different molecular weight profiles and superior antioxidant activity than the native bean protein.
\end{abstract}

Keywords: alcalase; antioxidant; molecular weight; pepsin; protein.

Practical Application: Protein concentrate and hydrolysates had antioxidant activity.

\section{Introduction}

Black bean (Phaseolus vulgaris L.) is the largest cultivated and consumed pulse legume in the world. Broken beans, known as "bandinha" in Brazil, are obtained after the harvest and post-harvest process of bean seeds. These seeds have the same nutritional composition of the whole grains, but low commercial value (Carvalho et al., 2012). The broken beans' cotyledons leave exposed the seed to the environment, which may cause undesirable microbial contamination and physical-chemical reactions. These potential adverse factors promote the necessity of consuming bandinha sooner than whole beans (Carvalho et al., 2012). The development of expanded extrudates from bandinha-based formulations was recently reported as an attempt to add value to bandinha (Berrios, 2006). Another way to improve the value of bandinha is the production of protein hydrolysates from their extracted proteins.

Protein hydrolysates have been used as priced value-added ingredient, with high protein digestibility and select amino acids, in special food processing applications. This type of food is essential for people with chronic diseases, such as Crohn's disease and Short bowel syndrome, which difficult the protein absorption in the native form. As well as, used in phenylketonuria or allergies and intolerances that makes basically impossible the absorption of specifics amino acids (Pacheco et al., 2005). Other potential uses of protein hydrolyzates are in sports nutrition, especially when high muscle resistance is required. In this case, amino acids and peptides are precursors for protein synthesis, performance and essential roles on the fast post-workout injury recovery and increasing the athlete performance.

Some studies with peptides from enzymatic hydrolysis of different food proteins, besides their nutritional value, showed human health benefits. These studies involve the use of commercial enzymes (alcalase, flavourzyme, pepsin, pancreatin, tripsin, chymotrypsin, neutrase, etc.) at different hydrolysis time, enzyme/substrate ratios, and enzyme's specific $\mathrm{pH}$ and temperatures (Alashi et al., 2014; Onuh et al., 2014; Ahn et al., 2012; Zhao et al., 2012; Fritz et al., 2011). The hydrolysis conditions and the specificity of the enzyme are key factors for protein hydrolysis, because these factors influence the sites and the peptide linkages that will be hydrolyzed. The resulted protein hydrolyzed material will have different characteristics and biological and functional properties (Avramenko et al., 2013). Among several reported benefits, the most evidenced are anti-hypertension, antioxidant, antimicrobial and anti-carcinogenic activities and the control of lipid metabolism (Roy et al., 2010). According Zhao et al. (2011) the bioactive properties of protein hydrolyzates are related to changes in the protein structure, which have been associated with the reduction in protein molecular weight, and the increase of the ionizable groups and hydrophobic groups' exposure that were hidden before hydrolysis. The objective of this research work was to study the enzymatic hydrolysis of pepsin and alcalase enzymes effects on black bean protein concentrate, with respect to the antioxidant properties of their hydrolyzates. 


\section{Materials and methods}

\subsection{Materials}

Black beans were obtained from a local market of the city of Pelotas, Rio Grande do Sul, Brazil. All the chemicals and reagents used in this study were of analytical grade. The pepsin $(\geq 400 \mathrm{U} / \mathrm{mg})$ and Alcalase ${ }^{\varpi}$ CLEA $(\geq 5 \mathrm{U} / \mathrm{g})$ enzymes were obtained from Sigma-Aldrich (St. Louis, MO, USA).

\subsection{Black bean protein extraction}

Black bean protein concentrate (BBPC) was prepared according to the method described by Carrasco-Castilla et al. (2012), with some modifications. The beans were ground in a laboratory mill (Perten 3100, Perten Instruments, Sweeden), using a 70 mesh sieve. Then, the bean flour was washed twice with $50 \%$ acetone $(\mathrm{v} / \mathrm{v})$, for $1 \mathrm{~h}$ each wash, to remove phenolic compounds. For protein extraction, the bean flour was suspended in distilled water (1:10, bean flour:water) and the $\mathrm{pH}$ of the slurry was adjusted to 9.5 with $1 \mathrm{~N} \mathrm{NaOH}$ under stirring for $30 \mathrm{~min}$ at $35^{\circ} \mathrm{C}$. Then, the slurry was centrifuged for $30 \mathrm{~min}$ at $12,000 \mathrm{x} \mathrm{g}$ and the supernatant was removed. The $\mathrm{pH}$ of the supernatant was adjusted to $\mathrm{pH} 4.5$ with $1 \mathrm{~N}$ $\mathrm{HCl}$ and further centrifuged at 12,000 g. The precipitated protein was stored at $-80{ }^{\circ} \mathrm{C}$ and lyophilized to obtain the bean protein concentrate.

\subsection{Protein hydrolysis}

The BBPC hydrolysis was carried out according to the method described by Carrasco-Castilla et al. (2012). The BBPC was suspended in $35 \mathrm{mM}$ sodium phosphate buffer $(5 \% \mathrm{w} / \mathrm{v})$ and left stirring overnight at $4{ }^{\circ} \mathrm{C}$. The enzyme: substrate ratio of $1: 20(\mathrm{w}: \mathrm{w})$ and reaction time of $120 \mathrm{~min}$, was used for the hydrolysis process. The hydrolysis of BBPC with pepsin enzyme (BBPHP) was performed at $37^{\circ} \mathrm{C}$ and $\mathrm{pH} 2.0$, while hydrolysis with alcalase enzyme (BBPHA) was conducted at $50{ }^{\circ} \mathrm{C}$ and $\mathrm{pH}$ 7.0. After the hydrolysis process, the bean protein hydrolysates were immediately heated at $90{ }^{\circ} \mathrm{C}$ for $10 \mathrm{~min}$ to inactivate the enzymes; follow by centrifugation at $10,000 \mathrm{~g}$ for $15 \mathrm{~min}$ and collection of the hydrolyzed supernatants.

\subsection{Proximate composition}

The proximate composition of the black bean, BBPC and the hydrolysates was determined according to methods of American Association of Cereal Chemists (1995). The moisture content of the samples was determined using a drying oven set at $105^{\circ} \mathrm{C} \pm 3{ }^{\circ} \mathrm{C}$, with natural air circulation for $24 \mathrm{~h}$. Fat content was determined following method 30-20 (American Association of Cereal Chemists, 1995). Nitrogen content was determined according to AACC method 46-13 (American Association of Cereal Chemists, 1995), and the protein content was obtained using a conversion factor of nitrogen to protein of 6.25. Ash content was determined according to the AACC method 08-01 (American Association of Cereal Chemists, 1995). The total carbohydrates were estimated by difference of constituents. The proximal composition was expressed on dry basis (d.b).

\subsection{SDS-PAGE electrophoresis}

BBPC and the protein hydrolysates were separated by electrophoresis on classical SDS-PAGE gel (10\% SDS, $10 \%$ glycerol, $5 \% \beta$-mercaptoethanol and $0.1 \%$ ) at pH 6.8 (Laemmli, 1970). A mixture of standard proteins, with molecular weight in the range of 6.5 to $66 \mathrm{kDa}$, was used as molecular weight marker and the gels were stained with Comassie Blue.

\subsection{Antioxidant activity by DPPH method}

The antioxidant activity (AA\%) of BBPC and its hydrolyzates were measured with 1,10-diphenyl-2-picrylhydrazyl (DPPH) radicals according to the method of Xia et al. (2012). Aliquots of hydrolyzates samples $(1 \mathrm{~g} / \mathrm{L})$ were mixed $1: 1(\mathrm{v} / \mathrm{v})$ with $0.1 \times 10^{-3} \mathrm{M} \mathrm{DPPH}$ in anhydrous ethanol for $30 \mathrm{~min}$, in the dark. The absorbance of the samples was recorded spectrophotometrically on a UV mini-1240 model (Shimadzu, Kyoto, Japan) at $516 \mathrm{~nm}$ and the antioxidant activity of the samples was expressed based on the following Equation 1.

DPPH AA $(\%)=\left[1-\left(\frac{A_{s}}{A_{c}}\right)\right] \times 100$

where $\mathrm{A}_{\mathrm{s}}$ is absorbance of sample; and $\mathrm{A}_{\mathrm{c}}$ is absorbance values of the DPPH solution without sample.

\subsection{Antioxidant capacity by ABTS $^{\bullet+}$ method}

The $\mathrm{ABTS}^{\bullet+}$ assay was based on the method of Durak et al. (2013), with some modifications. The ABTS radical was prepared from the reaction of $5 \mathrm{~mL}$ of $7 \mathrm{mM}$ ABTS solution and $88 \mu \mathrm{L}$ of $140 \mathrm{mM}$ potassium persulfate solution. The mixture was kept in the dark at room temperature for $16 \mathrm{~h}$. One hundred micro liters of the mixture were diluted with ethyl alcohol to obtain absorbance values from $0.70 \pm 0.05$ to $734 \mathrm{~nm}$. To promote the reaction of protein with the radical $\mathrm{ABTS}^{\bullet+}$, an aliquot of $0.1 \mathrm{~mL}$ of BBPC or protein hydrolyzate $(1 \mathrm{~g} / \mathrm{L})$ was added to $1.9 \mathrm{~mL}$ of $\mathrm{ABTS}^{\bullet+}$ and the absorbance was recorded after six minute of reaction. The control consisted of $35 \mathrm{mM}$ sodium phosphate buffer $\mathrm{pH} 7.8$, prepared under the same conditions of the test, but without sample. The percentage of inhibition of the $\mathrm{ABTS}^{+}$radical was then calculated using the following Equation 2.

$\operatorname{ABTS}$ AA $(\%)=\left[1-\left(\frac{A_{s}}{A_{c}}\right)\right] \times 100$

where $\mathrm{A}_{\mathrm{s}}$ is absorbance of sample; and $\mathrm{A}_{\mathrm{c}}$ is absorbance values of the sodium phosphate buffer solution without sample.

\subsection{Statistical analysis}

All analyses were performed in triplicate. Data analysis was carried out by analysis of variance (ANOVA). Comparison of the means was performed by Tukey's test at $5 \%$ level of significance. 


\section{Results and discussion}

\subsection{Chemical composition}

The proximate composition of black beans is $23.1 \%$ protein, $4.3 \%$ ash, $1.2 \%$ fat, $71.4 \%$ of total carbohydrate. The protein and ash contents of black bean protein hydrolysates prepared with pepsin and alcalase enzymes are presented in Figure 1. The black bean protein concentrate presented the following proximate composition: $81.6 \%$ protein, $6.2 \%$ ash, $0.8 \%$ fat and $11.4 \%$ of total carbohydrate. The protein content of the protein concentrate obtained in the present study was higher than the protein content of Mung bean and hard-to-cook black bean concentrates reported by Li et al. (2010) and Segura-Campos et al. (2012), respectively. There was a significant $(\mathrm{p}<0.05)$ decrease of $18.0 \%$ and $7.0 \%$ in the protein content of BBPHP $120 \mathrm{~min}$ and BBPHA $120 \mathrm{~min}$, respectively. These reductions in protein content were associated with an increase in the ash content of black bean protein hydrolysates, as observed in Figure 1 . Yust et al. (2010) also determined a decrease in protein content and an increase in ash content of chickpea protein hydrolysates obtained by alcalase digestion. According to the authors, the increase in ash content occurred due to the addition of alkali to keep the $\mathrm{pH}$ constant during hydrolysis. In the present study, the black bean protein hydrolysates obtained from pepsin digestion presented significantly higher $(\mathrm{p}<0.05)$ ash content compared to the ash content of protein hydrolysates obtained from alcalase digestion. The higher values in ash content presented by the hydrolysates obtained from pepsin can be attributed to the low $\mathrm{pH}(\mathrm{pH}$ 2.0) required for hydrolysis, which in turn, required higher amount of acid to achieve and maintain a constant $\mathrm{pH}$ during the hydrolysis reation.

The use of pepsin or alcalase enzymes had no effect on the fat content of the hydrolysatess, which was lower than $0.15 \%$ in all treatments. The total carbohydrate content was significantly higher $(\mathrm{p}<0.05)$ in the hydrolysates obtained from pepsin treatment, compared to those obtained from alcalase treatment.

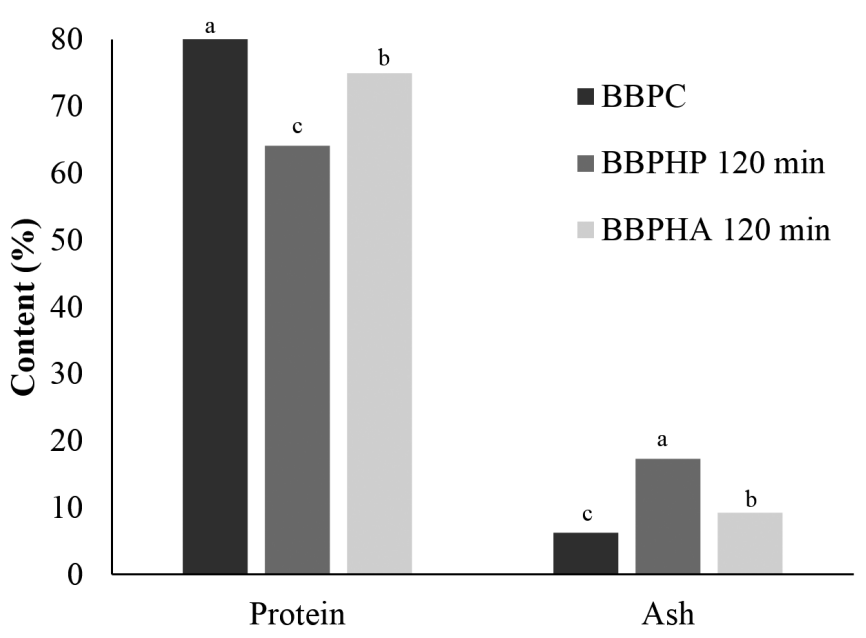

Figure 1. Protein and ash contents of black bean protein concentrate and its hydrolysates, using pepsin (BBPHP) and alcalase (BBPHA) enzymes. Different letters for each parameter are statistically different $(\mathrm{p}<0.05)$. The proximal composition was expressed on dry basis (d.b).
These results corroborates well with the protein content data, which indicated the lower purity of the hydrolysates obtained from pepsin digestion.

\subsection{SDS-PAGE eletrophoresis}

The molecular weight subunits of the $\mathrm{BBCP}$ and their hydrolysates were determined by SDS-PAGE (Figure 2). The first column of the gel (Std) represent the standard molecular weight, and in the others columns are presented the molecular weight subunits of BBPC (A), and those from the hydrolyzates of BBPC by pepsin (B) and alcalase (C), respectively. The faseolamin (7s) is the major storage protein of black beans. This main globulin fraction corresponds to $40 \%$ to $50 \%$ of the bean's proteins. This oligomeric protein is composed of three polypeptide subunits $-\alpha, \beta$ e $\gamma$ - with molecular weight between $43 \mathrm{kDa}$ to $53 \mathrm{kDa}$ (Yin et al., 2008). While the other globulin's fraction, the legumins (11S), correspond to only $10 \%$ of the bean's proteins (Montoya et al., 2010). Electrophoretic bands correspondent to faseolin fraction ( $47 \mathrm{kDa}$ and $44 \mathrm{kDa}$ ) were observed in both BBPC and the hydrolysates. The electrophoretic band at $31 \mathrm{kDa}$, corresponding to Phytohemagglutinin, was also noticed in all samples. These bands were also reported by Morales de León et al. (2005) for hard-to-cook (HTC) and young bean (Phaseolus vulgaris L.) protein concentrate.

The bands above $50 \mathrm{kDa}$ observed in the BBPC disappeared in the hydrolysate from pepsin (Figure 2B). According to Makri \& Doxastakis (2006), the molecular weight bands larger than $57 \mathrm{kDa}$ correspond to the $11 \mathrm{~S}$ fraction of bean storage proteins. Thus, the disappearing of the band between $45-66 \mathrm{kDa}$, after BBPC was hydrolyzed by pepsin, indicates that the $11 \mathrm{~S}$ fraction was broken down into smaller size molecular weight fractions.

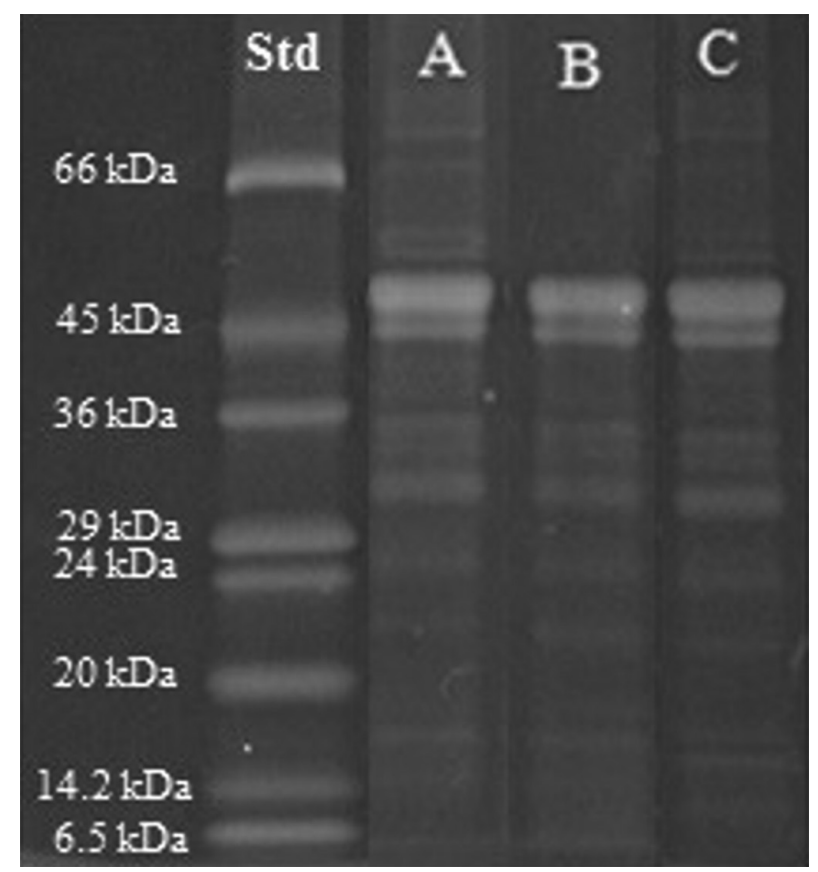

Figure 2. SDS/PAGE of standard molecular weight (Std), black bean protein concentrate (A), hydrolyzed by pepsin (B) and hydrolyzed by alcalase (C) for $120 \mathrm{~min}$, respectively. 
Table 1. Antioxidant activity of black bean protein concentrate (BBPC), and BBPC hydrolyzed by pepsin (BBPHP) or alcalase (BBPHA) for $120 \mathrm{~min}$

\begin{tabular}{|c|c|c|}
\hline Treatment $^{\mathrm{a}}$ & ABTS $^{\bullet+}$ & $\mathrm{DPPH}$ \\
\hline $\mathrm{BBPC}^{\mathrm{b}}$ & $55.32 \pm 0.08 b$ & $39.45 \pm 0.77 b$ \\
\hline BBPHP $120 \mathrm{~min}^{\mathrm{c}}$ & $47.04 \pm 0.46 c$ & $45.15 \pm 0.93 \mathrm{a}$ \\
\hline BBPHA $120 \min ^{\mathrm{d}}$ & $63.56 \pm 0.44 a$ & $37.15 \pm 0.27 c$ \\
\hline
\end{tabular}

${ }^{a}$ Results are the means of three determinations \pm standard deviation. Values accompanied by different letters in the same column are statistically different $(\mathrm{p}<0.05) .{ }^{\mathrm{b}} \mathrm{BBPC}=$ black bean protein concentrate. ${ }^{c}$ BBPHP $120 \mathrm{~min}=$ black bean concentrate protein hydrolyzed by pepsin for $120 \mathrm{~min} .{ }^{\mathrm{d}}$ BPHA $120 \mathrm{~min}=$ black bean concentrate protein hydrolyzed by alcalase for $120 \mathrm{~min}$.

\subsection{Antioxidant activity}

The antioxidant activity, based on $\mathrm{ABTS}^{\bullet+}$ and DPPH scavenge radicals' capacity, of the BBPC and its hydrolysates, using pepsin (BBPHP $120 \mathrm{~min}$ ) or alcalase (BBPHA $120 \mathrm{~min}$ ) enzymes, are presented in Table 1.

Based on ABTS $^{\bullet+}$ scavenge radical's capacity, BBPHA had higher antioxidant capacity than the BBPC and BBPHP. Re et al. (1999) postulated that the $\mathrm{ABTS}^{\bullet+}$ is able to scavenge hydrophobic and hydrophilic proteins radicals. The highest antioxidant capacity of BBPHA can be attributed to the larger hydrophobic group exposure than those of BBPHP. The hydrophobic groups were considered to be hidden into the tertiary and quaternary protein conformation, before hydrolysis of the protein.

However, based on DPPH antioxidant activity, BBPHP had higher proportion of antioxidant activity than the BBCP and the BBPHA (Table 1). Valdez-Ortiz et al. (2012) studied Azufrado bean (Phaseolus vulgaris) protein concentrate hydrolyzed by pepsin for 2 hours and reported that the protein hydrolysate presented $44 \%$ antioxidant activity by DPPH and $73 \%$ scavenge radical's ability by $\mathrm{ABTS}^{\bullet+}$.

The BBPHP had low molecular weight bands at 14.3 and $6.5 \mathrm{kDa}$ (Figure 2) probably due to the protein's high molecular weight breakdown by the enzyme. Although, Zhao et al. (2011) associated the molecular weight decrease with antioxidant activity, in this study that relationship was not observed.

\section{Conclusions}

The use of different enzymes, namely pepsin and alcalase, to prepare black bean protein hydrolysates under the same reaction time, resulted in different SDS-PAGE electrophoresis profile. The disappearance of high molecular weight bands and the appearance of low molecular weight bands in the electrophoretic gel, was indicative of the hydrolysis effect of the enzymes on the bean protein.

The black bean protein hydrolyzed by alcalase had the highest ABTS $^{\bullet+}$ antioxidant capacity of $63.56 \%$. While the black bean protein hydrolyzed by pepsin had the highest antioxidant activity of $45.15 \%$. Based on the results of this study, the black bean protein hydrolysates could be used as valuable protein ingredients with high antioxidant activity and high digestibility in specialty diets. Also, the results of this study foster new studies aiming to apply black bean hydrolysed with alcalase in food systems.

\section{Acknowledgements}

We would like to thank to $\mathrm{CNPq}$ by project financing, CAPES, FAPERGS, SCT-RS and Polos Tecnológicos for the scholarship and financial.

\section{References}

Ahn, C. B., Je, J. Y., \& Cho, Y. S. (2012). Antioxidant and anti-inflammatory peptide fraction from salmon byproduct protein hydrolysates by peptic hydrolysis. Food Research International, 49(1), 92-98. http:// dx.doi.org/10.1016/j.foodres.2012.08.002.

Alashi, A. M., Blanchard, C. L., Mailer, J. R., Agboola, S., Mawson, J. A., He, R., Girgih, A., \& Aluko, R. E. (2014). Antioxidant properties of Australian canola meal protein hydrolysates. Food Chemistry, 146(1), 500-506. http://dx.doi.org/10.1016/j.foodchem.2013.09.081. PMid:24176374.

American Association of Cereal Chemists - AACC. (1995). Approved methods of the American Association of Cereal Chemists. St. Paul: AACC.

Avramenko, N. A., Low, N. H., \& Nickerson, M. T. T. (2013). The effects of limited enzymatic hydrolysis on the physicochemical and emulsifying properties of a lentil protein isolate. Food Research International, 52(1), 162-169. http://dx.doi.org/10.1016/j.foodres.2012.11.020.

Berrios, J. J. (2006). Extrusion cooking of legumes: dry bean flours. In D. R. Heldman \& C. I. Moraru (Eds.), Encyclopedia of Agricultural, Food and Biological Engineering (1st ed., pp. 1-8). New York: Taylor and Francis Group.

Carrasco-Castilla, J., Hernández-Álvarez, A. J., Jiménez-Martínez, C., Jacinto-Hernández, C., Alaiz, M., Girón-Calle, J., Vioque, J., \& Dávila-Ortiz, G. (2012). Antioxidant and metal chelating activities of peptide fractions from phaseolin and bean protein hydrolysates. Food Chemistry, 135(3), 1789-1795. http://dx.doi.org/10.1016/j. foodchem.2012.06.016. PMid:22953924.

Carvalho, A. V., Bassinello, P. Z., Mattietto, R. A., Carvalho, R. N., Rios, A. O., \& Seccadio, L. L. (2012). Processamento e caracterização de snack extrudado a partir de farinhas de quirera de arroz e de bandinha de feijão. Brazilian Journal of Food Technology, 15(1), 72-83. http:// dx.doi.org/10.1590/S1981-67232012000100008.

Durak, A., Baraniak, B., Jakubczyk, A., \& Świeca, M. (2013). Biologically active peptides obtained by enzymatic hydrolysis of Adzuki bean seeds. Food Chemistry, 141(3), 2177-2183. http://dx.doi.org/10.1016/j. foodchem.2013.05.012. PMid:23870945.

Fritz, M., Vecchi, B., Rinaldi, G., \& Añón, M. (2011). Amaranth seed protein hydrolysates have in vivo and in vitro antihypertensive activity. Food Chemistry, 126(3), 878-884. http://dx.doi.org/10.1016/j. foodchem.2010.11.065.

Laemmli, U. K. (1970). Cleavage of structural proteins during the assembly of the head of the head of bacteriophage T4. Nature, 227(5259), 680685. http://dx.doi.org/10.1038/227680a0. PMid:5432063.

Li, W., Shu, C., Yan, S., \& Shen, Q. (2010). Characteristics of sixteen mung bean cultivars and their protein isolates. International Journal of Food Science \& Technology, 45(6), 1205-1211. http://dx.doi. org/10.1111/j.1365-2621.2010.02259.x.

Makri, E. A., \& Doxastakis, G. I. (2006). Emulsifying and foaming properties of Phaseolus vulgaris and coccineus proteins. Food Chemistry, 98(3), 558-568. http://dx.doi.org/10.1016/j.foodchem.2005.06.027.

Montoya, C. A., Lallès, J. P., Beebe, S., \& Leterme, P. (2010). Phaseolin diversity as a possible strategy to improve the nutritional value of common beans (Phaseolus vulgaris). Food Research International, 43(1), 443-449. http://dx.doi.org/10.1016/j.foodres.2009.09.040. 
Morales de León, J., Camacho, M. E., \& Bourges, H. (2005). Amino acid composition of some Mexican foods. Archivos Latinoamericanos de Nutricion, 55(1), 172-186. PMid:16335228.

Onuh, J. O., Girgih, A. T., Aluko, R. E., \& Aliani, M. (2014). Inhibitions of renin and angiotensin converting enzyme activities by enzymatic chicken skin protein hydrolysates. Food Research International, 53(1), 260-267. http://dx.doi.org/10.1016/j.foodres.2013.05.010.

Pacheco, M. T. B., Dias, N. F. G., Baldini, V. L. S., Tanikawa, C., \& Sgarbieri, V. C. (2005). Propriedades funcionais de hidrolisados obtidos a partir de concentrados proteicos de soro de leite. Ciência e Tecnologia de Alimentos, 25(2), 333-338. http://dx.doi.org/10.1590/ S0101-20612005000200026.

Re, R., Pellegrini, N., Proteggente, A., Pannala, A., Yang, M., \& RiceEvans, C. (1999). Antioxidant activity appllying an improved ABTS radical cation decolorization assay. Free Radical Biology \& Medicine, 26(9-10), 1231-1237. http://dx.doi.org/10.1016/S08915849(98)00315-3. PMid:10381194.

Roy, F., Boye, J. I., \& Simpson, B. K. (2010). Bioactive proteins and peptides in pulse crops: pea, chickpea and lentil. Food Research International, 43(2), 432-442. http://dx.doi.org/10.1016/j.foodres.2009.09.002.

Segura-Campos, M., Ruiz-Ruiz, J., Chel-Guerrero, L., \& BetancurAncona, D. (2012). Antioxidant activity of Vigna unguiculata L. walp and hard-to-cook Phaseolus vulgaris L. protein hydrolysates. CyTA. Journal of Food, 1(3), 1-8.

Valdez-Ortiz, A., Fuentes-Gutiérrez, C. I., Germán-Báez, L. J., GutiérrezDorado, R., \& Medina-Godoy, S. (2012). Protein hydrolysates obtained from Azufrado (sulphur yellow) beans (Phaseolus vulgaris): nutritional, ACE-inhibitory and antioxidative characterization. LWT - Food Science and Technology, 46(1), 91-96. http://dx.doi. org/10.1016/j.lwt.2011.10.021.

Xia, Y., Bamdad, F., Gänzle, M., \& Chen, L. (2012). Fractionation and characterization of antioxidant peptides derived from barley glutelin by enzymatic hydrolysis. Food Chemistry, 134(3), 1509-1518. http:// dx.doi.org/10.1016/j.foodchem.2012.03.063. PMid:25005974.

Yin, S.-W., Tang, C.-H., Wen, Q.-B., Yang, X.-Q., \& Li, L. (2008). Functional properties an in vitro trypsin digestibility of red kidney bean (Phaseolus vulgaris L.) protein isolate: effect of high-pressure treatment. Food Chemistry, 110(4), 938-945. http://dx.doi.org/10.1016/j. foodchem.2008.02.090. PMid:26047283.

Yust, M. M., Pedroche, J., Millán-Linares, M. C., Alcaide-Hidalgo, J. M., \& Millán, F. (2010). Improvement of functional properties of chickpea proteins by hydrolysis with immobilised Alcalase. Food Chemistry, 122(4), 1212-1217. http://dx.doi.org/10.1016/j. foodchem.2010.03.121.

Zhao, G., Liu, Y., Zhao, M., Ren, J., \& Yang, B. (2011). Enzymatic hydrolysis and their effects on conformational and functional properties of peanut protein isolate. Food Chemistry, 127(4), 1438-1443. http:// dx.doi.org/10.1016/j.foodchem.2011.01.046.

Zhao, Q., Selomulya, C., Xiong, H., Chen, X. D., Ruan, X., Wang, S., Xie, J., Peng, H., Sun, W., \& Zhou, Q. (2012). Comparison of functional and structural properties of native and industrial process-modified proteins from long-grain indica rice. Journal of Cereal Science, 56(1), 568-575. http://dx.doi.org/10.1016/j.jcs.2012.08.012. 